\title{
Pomarańcze na drutach Witolda Wirpszy. Kłopoty z rozumieniem eksperymentu prozatorskiego w świetle przed-tekstu
}

\section{Dariusz Pawelec}

\author{
ORCID: 0000-0002-1397-2082
}

W listopadzie 1964 roku, kiedy ukończono druk powieści Pomarańcze na drutach, Witold Wirpsza znany był głównie jako poeta. Każdy tom jego wierszy, począwszy od debiutanckiej Sonaty z 1949 roku, mógł liczyć na najpełniejszą z możliwych recepcję w prasie kulturalnej. Dość powiedzieć, że pierwszym recenzentem tego debiutu był, na łamach „Twórczości”, rozpoczynający swą przygodę krytycznoliteracką Jan Błoński ${ }^{1}$. Na liście wnikliwych komentatorów kolejnych zbiorów znaleźli się później między innymi Jerzy Kwiatkowski, Jan Józef Lipski, Paweł Beylin, Jacek Trznadel, Ryszard Matuszewski, Zbigniew Żabicki, Julian Rogoziński, Alicja Lisiecka, Stanisław Barańczak. W roku 1964 Wirpsza był także rozpoznawalnym eseistą, krytykiem teatralnym i początkującym dramaturgiem (autorem dwóch sztuk opublikowanych w „Dialogu”), cenionym tłumaczem (m.in. Doktora Faustusa, wspólnie z żoną Marią Kurecką), redaktorem i publicystą rozwiązanego przez władze „Po prostu” i „Nowej Kultury”, z której odszedł w geście protestu przeciwko ingerencjom partii w zarządzanie pismem w 1958 roku, notabene razem z Leszkiem Kołakowskim, Wiktorem Woroszylskim i Tadeuszem Konwickim. Z dzisiejszej perspektywy powieść Pomarańcze na drutach można by uznać za jego debiut prozatorski, choć w roku 1964 całkiem świeża musiała być jeszcze pamięć o socrealistycznych początkach tej twórczości, w tym o powieści Na granicy (1954) i zbiorze opowiadań Stary tramwaj (1955). Pierwszy z tych tytułów poświęcony jest robotnicom wywiezionym do pracy przymusowej w Niemczech i polonizacji Szczecina, drugi - przetwarza na potrzeby fikcji autobiograficzne doświadczenia między innymi ze stalagu, z wyraźną koncesją na rzecz obowiązującej wówczas tendencji.

\footnotetext{
${ }^{1}$ Jan Błoński, „Dwaj poeci”, Twórczość, nr 3 (1950): 113-123.
} 
Odbiór nowej powieści Wirpszy dokonał się jednak bez przywoływania jego socrealistycznych prób prozatorskich, a jego naturalnym kontekstem była nowoczesna, uznana przez krytyków za eksperymentalną, twórczość poetycka, szczególnie ze zbiorów ogłoszonych na początku lat 60.: Maty gatunek (1960), Don Juan (1960), Komentarze do fotografii: The Family of Man (1962). Gdyby podsumowywać sądy dominujące w recepcji tych tomów, niezależnie od tego, czy opinie należały do przychylnych, czy raczej krytycznych, to znajdziemy w nich najczęściej takie kategorie, jak intelektualizm, uczoność i hermetyzm, mające stanowić o przekraczaniu przez poetę granic zrozumiałości i eksperymentu. Leszek Szaruga, syn pisarza, zapytany o to jak ten reagował na recepcję własnych dokonań, odpowiadał, że „jeśli chodzi o powieści ojca, tutaj owszem, mógł myśleć, że będzie miał jakiegoś typowego czytelnika”, tyle że „Pomarańcze na drutach są jednak za trudne dla zwykłego odbiorcy"2. Dokładnie taką samą ocenę znajdziemy w pierwszych dwóch recenzjach powieści z roku 1965. Rafał Marszałek uznał, że to „chyba najdziwniejsza proza, jaka ukazała się u nas ostatnio”, „Powieść, która nie ma akcji w potocznym tego słowa rozumieniu i która napisana została w formie nadzwyczaj trudnej - chciałoby się rzec: opornej wobec tworzywa - zasługuje na nazwę eksperymentalnej”3. Edward Balcerzan, nazywając Pomarańcze na drutach „wydarzeniem literackim klasy europejskiej”, uznał ją za „powieść w każdym calu nowatorską”, „wynalazek”, który „będzie sprawiał kłopoty czytelnikom”, bo nie pomogą im „żadne wzory literackie”.

Skąd brały się te kłopoty z rozumieniem? „Niepowodzenia Wirpszy na tym polu” upatrywał Rafał Marszałek w „nadmiernej komplikacji formalnej, polegającej przede wszystkim na wyjątkowej drobiazgowości opisu i wymyślności składni”, co przejawia się między innymi w postaci „ekscentrycznie spisywanych dialogów”, „długich powikłanych okresów” i „synonimicznych powtórzeń" . Od analizy składni rozpoczyna swoją recenzję Balcerzan, ilustrując fragmentami dzieła rozmaite jej „osobliwości”, takie jak: „nienaturalna dokładność opisu, ścisłość beznamiętna, rejestracja słów i gestów bez względu na ich ważność”, „wrażliwość na pauzę w żywej mowie" ${ }^{\prime}$. Z celowości tych zabiegów artystycznych wyprowadził Balcerzan wniosek o sprawdzaniu przez narratora Wirpszy poznawczej wartości mitu cybernetycznego, narratora, który udaje automat. W związku z tym „to wszystko, co odbiorca mógłby uznać za dziwactwo stylistyczne, jest naprawdę dramatyczną walką maszyny z językiem"”. Analiza składniowego klucza do rozumienia powieści prowadzi recenzenta do odkrycia bardzo precyzyjnie skatalogowanych przezeń paraleli z poezją: dialogi ucięte „wbrew przyjętym zasadom składni” postrzega krytyk jako rozwiązanie analogiczne do zasad organizacji wiersza wolnego, w innych partiach narracji znajduje „prawa sylabotonizmu” albo „odcinki heksametru”. W opinii Rafała Marszałka język w powieści Wirpszy „pełni rolę samoistną jako przedmiot groteskowych przekształcen”, i to właśnie przekształcenia językowe, kosztem innych elementów całego układu, są dla autora „czymś szczególnie ważnym i atrakcyjnym”. Od takiej tezy blisko już do wniosku, że „ostatecz-

\footnotetext{
2 „Istnieje porządek nieodgadniony”. O Witoldzie Wirpszy z Leszkiem Szarugą rozmawia Karol Samsel, Elewator, nr 23 (2018): 45.

${ }^{3}$ Rafał Marszałek, „Eksperyment Wirpszy”, Nowe Ksiq̨żki, nr 9 (1965): 402.

${ }^{4}$ Edward Balcerzan, „Człowiek Witolda Wirpszy”, Nurt, nr 2 (1965): 48-49.

${ }^{5}$ Marszałek, „Eksperyment Wirpszy”, 403.

${ }^{6}$ Balcerzan, „Człowiek Witolda Wirpszy”, 48.

${ }^{7}$ Balcerzan.

${ }^{8}$ Balcerzan.

${ }^{9}$ Marszałek, „Eksperyment Wirpszy”, 403.
} 
nie najbardziej znamiennym sensem eksperymentu uwiecznionego w tytule jest to, że hermetyczną, ale bogatą znaczeniami prozę Pomarańczy na drutach napisał - poeta"10. Arnold Słucki podkreślił bliskie sąsiedztwo w procesie wydawniczym tomu Wirpszy pt. Drugi opór (1965), zawierającego wiersze z lat 1960-1964, z „powieścią eksperymentalną”, jak określa Pomarańcze na drutach, uznając ją za „rzecz nie obojętną, gdy chodzi o formowanie się poetyki autora Drugiego oporu”11. „Związek tej prozy - pisze Słucki - z dojrzałym kształtem poetyckim wierszy Wirpszy wymaga oddzielnego studium". Zwrócił przy tym uwagę zwłaszcza na operacje syntaktyczne w powieści, na jej „żywioł rytmiczny”, na zaczynający się w niej „proces kruszenia tradycyjnie pojmowanego obrazu poetyckiego, zabieg dezintegracyjny, dla którego poeta znaleźć chce później wytłumaczenie we współczesnej teorii kwantów”"12. „Autor Pomarańcz na drutach - to już opinia Tadeusza Nyczka - robi ostatnio poezję - jak prozę, i prozę - jak poezję"13.

Wczesny odbiór Pomarańczy na drutach zdominowany został zatem przez pytanie o jej formę, na co odpowiedzią stało się odesłanie czytelników recenzji do formy poetyckiej jako wyznacznika wartości i gwarancji sensu całego prozatorskiego przedsięwzięcia Wirpszy. Balcerzana zaprowadziło to do uznania narracji za podporządkowaną zasadom gry cybernetycznej, która kończy się fiaskiem: „maszyna” precyzyjnie opisała świat, ale na opisie tylko mogła poprzestać. Sposób potraktowania fabuły, ograniczonej możliwościami narratora-automatu, nie może dać odpowiedzi na pytania filozoficzne, które „leżą poza kompetencjami cybernetyki”"14. Marszałek demonstruje, jak proza poety, z językiem jako dominantą, operuje nadrzędną dla utworu kategorią groteski na dwóch poziomach: językowym i świata przedstawionego. Wirpsza, sytuując fabułę w obozie jenieckim, czyni głównym przedmiotem groteskowej kompozycji egzystencjalną kategorię wolności, układając udaną „mozaikę” problemów: „w jej obrębie mieszczą się wątki egzystencjalne pospołu z kompleksami inteligenckimi, problem polskości ujęty w tak różnych kontekstach, jak dziedzictwo tradycji i psychologia działania"15. Tyle że język potraktowany jako samoistny przedmiot groteski, niepodporządkowany funkcji kompozycyjnej, udziwnia powieść, czyniąc ją nadmiernie skomplikowaną w odbiorze, i zmusza niejako do odczytywania całości w sposób właściwy poezji. Artur Strumiłowski postawę twórczą Wirpszy określa jako „komplikacjonizm” - pisze on bowiem „powieść wariacyjną, w której całą swą wielką inwencję wyczerpuje w zabiegach stylistyczno-techniczno-kompozycyjnych, właśnie mających na celu zbliżenie utworu literackiego do formy dzieła muzycznego - i nie pozostaje mu dość czasu, aby zadbać jeszcze o fabułę"16.

Także w komentarzach zanotowanych z większego dystansu czasowego pojawiają się bardzo podobne spostrzeżenia. Piotr Kuncewicz, uznając Pomarańcze na drutach za powieść napisaną „techniką kontrapunktowo-wariacyjną”, zauważa, że „o tej prozie stanowią przeróżne pomysły formalne”, natomiast „wszystko tonie w dygresjach i akcja zajmuje właściwie skrawek książki”"

\footnotetext{
${ }^{10}$ Marszałek.

${ }^{11}$ Arnold Słucki, „Od «Sonaty» do «Drugiego oporu»", Twórczość, nr 1 (1966): 118.

${ }^{12}$ Słucki.

${ }^{13}$ Tadeusz Nyczek, „Śladem wzruszenia”, Poezja, nr 3 (1971): 24.

${ }^{14}$ Balcerzan, „Człowiek Witolda Wirpszy”, 49.

${ }^{15}$ Marszałek, „Eksperyment Wirpszy”, 403.

${ }^{16}$ Artur Strumiłowski, „Nowości prozy”, Życie Literackie, nr 44 (1965): 11.

${ }^{17}$ Piotr Kuncewicz, „Wirpsza i pozostali”, Przegląd Tygodniowy, nr 7 (1986), 13.
} 
Maciej Byliniak traktuje Pomarańcze na drutach jako najbardziej widoczny u Wirpszy przejaw „antyrealizmu”: „gdzie część dialogów to «dialogi pozorne», w których jedna wypowiedź została podzielona przez autora na części arbitralnie ( $\mathrm{z}$ punktu widzenia realizmu przedstawienia, ale nie z punktu widzenia kompozycji formalnej) przydzielone poszczególnym rozmówcom"18. W przekonaniu Zbigniewa Chojnowskiego w powieści „chodzi o samo rozprawianie, analizę, artystyczny dyskurs, napinanie, mnożenie, precyzowanie i dewastację znaczeń, zwielokrotnianie wątpliwości, wariacyjne ujęcie tematu, «żeglowanie» w języku i narracji”"19.

Co ciekawe, w jednej z najnowszych interpretacji powieści, uznanej za doskonałą i prekursorską, wątek przesłony formalnej i językowego odrealnienia w ogóle się nie pojawia. Maciej Libich (w szkicu z roku 2018) dostrzegł natomiast „intrygujące powiązanie, które łączy Pomarańcze na drutach z Nadzorować i karać autorstwa Michela Foucaulta”, a także z „innymi dziełami filozofów poststrukturalistycznych i postmodernistycznych, które starały się opisywać wielopłaszczyznowe relacje społeczeństwa, władzy, kary oraz systemów kontrolnych i penitencjarnych"20. Badacz proponuje także odczytywanie powieści z wykorzystaniem teorii czasu Krzysztofa Pomiana, wedle której „czas należy pojmować jako sieć hierarchicznych instancji kontrolujących życie społeczeństw"21. Zarówno przywołana praca Foucaulta, jak i Porządek czasu Pomiana są od dzieła Wirpszy późniejsze, stąd teza Libicha o jego prekursorskich aspektach. Wiele lat wcześniej Stanisław Barańczak wpisał powieść we właściwy dla Wirpszy w ogóle porządek demaskowania mitów. W wypadku tej prozy, rozważającej pojęcia wolności, przypadku i konieczności, chodzi o „odwieczne mity egzystencjalne”22. Rodzi się pytanie, szczególnie na tle innych przytoczonych dokumentów recepcji, czy takie sugestie interpretacyjne, dokonywane niejako obok językowej i „poetyckiej” tkanki tekstu albo ponad nią, są w ogóle możliwe i uprawnione? Czy może klucz do rozumienia powieści, „za trudnej” nawet ponad pół wieku po jej wydaniu, ukryty jest jednak, jak chcieli pierwsi recenzenci, w formalnych zabiegach, cybernetycznej grze narratora, udziwnionej technice opisu, nienaturalności i, wreszcie, w nastawieniu na sam język czy wręcz w „przedstawieniu języka” właściwemu sztuce poetyckiej, szczególnie w jej nurcie lingwistycznym?

Czytelnik Pomarańczy na drutach, nawet ten mający ogólną wiedzę na temat miejsca dokonań poetyckich Wirpszy na mapie najważniejszych tendencji w poezji polskiej drugiej połowy XX wieku, nie mógłby zapewne przystać na próby opanowywania kłopotów z rozumieniem jego powieści poza tym „lingwistycznym” kontekstem. Najdalej idące wnioski płynące z takiej postawy wyciągnął chyba Balcerzan. Tymczasem w otwierającym wydanie Pomarańczy na drutach słowie Od Autora pojawia się intrygujący trop dotyczący genezy tekstu, ważny także dla sposobu rozumienia samej formy powieściowej. Przytaczam odpowiednie fragmenty tekstu od jego początku:

\footnotetext{
${ }^{18}$ Maciej Byliniak, „Krytyka obrazu w poezji i eseistyce Witolda Wirpszy”, Twórczość, nr 8 (2009): 75.

${ }^{19}$ Zbigniew Chojnowski, „Zegar' i uwięzienie w powieści Witolda Wirpszy «Pomarańcze na drutach»”, w „W rytmie zegara...”. Wokół zagadnień chronozoficznych, red. Zbigniew Chojnowski, Beata Kurządkowska i Anna Rzymska (Olsztyn: Wydawnictwo UWM, 2015), 231.

${ }^{20}$ Maciej Libich, „Epistolograficzny nośnik poezji. Osiem notatek o «Listach z oflagu» Witolda Wirpszy”, Elewator, nr 23 (2018): 27.

${ }^{21}$ Libich.

${ }^{22}$ Stanisław Barańczak, „Na 60-lecie Witolda Wirpszy”, Kultura, nr 1 (1979): 107.
} 
Kiedy w latach czterdziestych, niedługo po wyzwoleniu, zabrałem się do napisania utworu prozą, który by w jakiś sposób spożytkował moje doświadczenia obozowe, nie bardzo jeszcze zdawałem sobie sprawę, jaki ostateczny kształt artystyczny ta proza przybierze; jedno tylko uświadomiłem sobie od razu: w utworze tym zawarty być musi element groteski. W ostatecznej fazie pisania ciążenie ku grotesce stało się tendencją dominującą, wręcz założeniem artystycznym.

Kilkadziesiąt stron pierwszej redakcji powstało jesienią 1946 roku; była to jeszcze - formalnie proza tradycyjna w dziewiętnastowiecznej konwencji. Brakowało mi natomiast dwóch składników zasadniczych: dystansu oraz takich koncepcji filozoficznych, które mogłyby służyć zabawie.

$[\ldots]$

Ta groteskowa kompromitacja i samokompromitacja wymagała określonej formy. Tradycyjna forma prozy, wywodząca się z werystycznej dziewiętnastowiecznej praktyki, wydawała mi się - po wielokrotnych próbach - niestosowna; skłoniło mnie to do poszukiwania pewnych sposobów zestawiania słów i znaczeń, które by stworzyły artystycznie skuteczną siatkę językową; taką siatkę, która stanowiłaby konsekwentną i systematyczną gmatwaninę krzyżujących się absurdalności oflagowego surowca; absurdalności wysupłanych z autentyku, z jego deformacji i jego wariantów i podniesionych przez ten proceder do rangi zwartego systemu: takiego systemu, który miałby szansę stać się uogólnieniem ${ }^{23}$.

Dzięki materiałom z archiwum pisarza zachowanym w Książnicy Pomorskiej w Szczecinie możemy ten pomijany dotychczas trop interpretacyjny zweryfikować. Zachowało się w sumie 65 kart maszynopisu zawierających polski tekst ${ }^{24}$ Pomarańczy na drutach, w tym 39 kart owej „pierwszej redakcji” powieści z jesieni 1946 roku. Trudno osądzić, czy są to wszystkie strony z „kilkudziesięciu”, o których mowa we wprowadzeniu do wydania z roku 1964. Na pozostałych zachowanych kartach, różniących się od owych 39 rodzajem papieru, a także noszących ślady korzystania z innej maszyny do pisania (wskazują na to liczne cechy, w tym na przykład znak diakrytyczny nad „n”, którego konsekwentnie brak na starszych kartach), znajdują się różne fragmenty tekstu w tej samej postaci, jaką znamy już z edycji PIW. Na ostatniej stronie z fragmentem, który w wydaniu książkowym stanowi część oznaczoną jako „3” (s. 23-33) ${ }^{25}$, ołówkiem dopisano datę: „20/VI 60”. Już w druku data ta znalazła się nie pod tym rozdziałem, ale dopiero na końcu powieści w zapisie bardziej rozbudowanym: „Warszawa, listopad 1946 czerwiec 1960". Porównanie obydwu podzbiorów maszynopisu, zarówno w wymiarze materialnym, jak i samego tekstu powieści, każe oddalić sugestię, zawartą w tej odautorskiej notacji, że praca nad tekstem trwała nieprzerwanie kilkanaście lat. Jesienią 1946 roku Wirpsza zamknął,

${ }^{23}$ Witold Wirpsza, Pomarańcze na drutach (Warszawa: PIW, 1964), 5-7.

${ }^{24}$ Dodatkowo zachowało się powiązanych z powieścią pięć kart maszynopisu w języku niemieckim: trzy z tekstem słowa Od Autora oraz dwie z opinią wydawniczą, niepodpisaną, ale prawdopodobnie autorstwa Lutza Adlera.

Opinia przeznaczona była dla wydawnictwa Hanser. Zob. na ten temat: Witold Wirpsza, Heinrich Kunstmann, „Salut Henri! Don Witoldo!”. Witold Wirpsza - Heinrich Kunstmann. Listy 1960-1983, wstęp, przekład i oprac. Dorota Cygan i Marek Zybura (Kraków: Universitas, 2015), 72.

${ }^{25} \mathrm{~W}$ wersji drukowanej powieść, oprócz słowa Od Autora, składa się z 21 ponumerowanych w ten sposób podrozdziałów. W zapisie z roku 1946, poza Przedsłowiem, mamy rozdziały numerowane i tytułowane. Zachowały się: Rozdział I Wieczór Trzech Króli, Rozdział II Co się dzieje w baraku oficerskim, Rozdział III Na spacerze, Rozdział IV Wyższa szkoła jazdy, Rozdział V Jak wyrastają pomarańcze, Rozdział VI Kawiarniane intermezzo. 
o czym pisze w cytowanym słowie Od Autora, pierwszą redakcję dzieła, aby następnie, po latach, napisać je od nowa i niejako od początku, a na pewno całkowicie inaczej. W krótkim „życiorysie artystycznym" dołączonym przez Wirpszę do listu z 12 lutego 1961 roku, którego adresatem był Heinrich Kunstmann, rękopis Pomarańczy na drutach umieszczony został przez autora jako dokonanie roku 196026. Miał zatem rację Arnold Słucki, wskazując na konieczność postrzegania nowego, lingwistycznego, eksperymentalnego Wirpszy-poety z tomów ogłaszanych w latach 60. w łączności z formowaniem się tej poetyki w równoległych pracach nad powieścią.

Pisząc list do Kunstmanna Wirpsza był przekonany, że jego powieść ukaże się drukiem w roku 1961. Autor, korzystając z zainteresowania, jakie w ocenie dzieła okazał jego respondent, podjął próbę dotarcia do wydawców niemieckich, co zakończyło się zresztą sukcesem ${ }^{27}$. O pomyślnym zakończeniu druku w Polsce mógł poinformować dopiero w styczniu 1965 roku. Wcześniej, w liście do Kunstmanna z 28 grudnia 1962 roku pisał następująco: „Za Pańskie zachody wokół Pomarańczy na drutach szczerze Panu dziękuję. Zdaję sobie całkowicie sprawę, uwzględniając właściwości tego tekstu, że znalezienie dla niego wydawcy nie jest wcale rzeczą łatwą. Tutaj w kraju zabiegam już od ponad dwóch lat o publikację (i dzieje się tak bynajmniej nie z powodów politycznych!), ale dopiero teraz widzę światło w tunelu"28. Dla zrozumienia nowego kształtu powieści szczególnie istotna jest ta ostatnia informacja, albowiem nie wskazuje ona na bezpośredni udział cenzury w procesie formowania się finalnego tekstu. Potwierdza to porównanie zachowanych kart maszynopisu nowej wersji powieści z gotową książką: nie doszukamy się żadnych różnic. Otwarte pozostaje pytanie o rolę autocenzury. W wersji z roku 1960 nie znajdziemy bowiem tych zapisów z roku 1946, które mogłyby potencjalnie budzić zastrzeżenia co do ich politycznej poprawności, jak na przykład konsekwentne używanie słowa „bolszewicy” czy wspomnienie oficerskiego „chrztu bojowego” w roku 1920.

Nie to jednak stanowi o istotnej odmienności obydwu wersji powieści, ale sygnalizowana przez autora we wstępie do wydania z roku 1964 sprawa formy. Zachowane, całkowicie inne od tego wstępu, jednostronicowe Przedsłowie do wersji pierwotnej także poświęcone jest kwestiom konwencji artystycznej:

Te kilka słów wstępu piszę dla tych czytelników, którzy razem ze mną spędzili lata niewoli. Być może pewne postaci i pewne sytuacje nasuną im obrazy ludzi, których znali czy sytuacji, jakie przeżyli. W związku z tym mam do nich prośbę: panowie, na Dzeusa - nie identyfikujcie! Tak, jak nikogo nie nazwałem po imieniu, tak samo nie chcę nikogo wskazywać palcem.

\footnotetext{
${ }^{26}$ Wirpsza, Kunstmann, „Salut Henri! Don Witoldo!”..., 45.

${ }^{27} \mathrm{Nie}$ tylko rozumianym jako zwieńczenie starań o druk książki w przekładzie Marii Kureckiej: Orangen im Stacheldraht (Monachium: Hanser, 1967). Nie był to oczywiście sukces w wymiarze komercyjnym, ale nie można wykluczyć, że to między innymi recepcja powieści w Niemczech przyczyniła się do zaproszenia Wirpszy do wygłoszenia uroczystej mowy na otwarcie Międzynarodowych Targów Książki we Frankfurcie 11 października 1967 roku. Zob. omówienia w prasie niemieckiej: Peter Urban, „Die Stacheldrahtfrüchte. Ein Roman des Polen Witold Wirpsza”, Die Zeit, 4.08.1967; Valentin Polcuch, „Freiheit und Zeit. Witold Wirpsza. Orangen im Stacheldraht”, Die Welt der Literatur, 8.06.1967; German Werth, „Früchte, die zu hoch hängen”, Der Tagesspiegel, 5.11.1967. O okolicznościach pierwszej niemieckiej edycji zob. Daniel Pietrek, „«Pomarańcze na drutach» - Witold Wirpsza w monachijskim wydawnictwie Carla Hansera”, w Filologia trudnego sqsiedztwa. Tom studiów dedykowany Profesorowi Markowi Zyburze w 60-lecie urodzin, red. Krzysztof Ruchniewicz, we współpracy z Piotrem Przybyłą i Dariuszem Wojtaszynem (Wrocław: Quaestio, 2017), 125-137. Już po śmierci autora doszło do drugiego wydania niemieckiego (Berlin: Westberliner Oberbaumverlag, 1987).

${ }^{28}$ Wirpsza, Kunstmann, „Salut Henri! Don Witoldo!”..., 70.
} 
Pomarańcze na drutach są powieścią o oflagu, ale o oflagu fantastycznym, który w rzeczywistości nigdy nie istniał. Poza tym - powieść ta stara się być nie wiernym obrazem przeżyć czy zaobserwowanych faktów, ale ich karykaturą - i to karykaturą przeciętnego stanu rzeczy, jaki istniał w obozach jeńców na terenie Rzeszy. - Przy konstrukcji osób działających używałem metody, że się tak wyrażę „syntetycznej”. Po prostu brałem z pewnej ilości zapamiętanych osób pewne cechy i, mieszając je ze sobą, otrzymywałem nowe, papierowe twory ludzkie. Mam zresztą wrażenie, że po przeczytaniu całości, każdy będzie gotów mi przyznać, że karykatura ta ani na chwilę nie miała zamiaru stać się paszkwilem.

Jest jeszcze druga strona medalu. Satyra ma swoje wymagania. Jeśli w ogólnym obrazie powieści osąd pewnych grup w obozie wypadnie ujemnie - to nie ma na to rady. Prawem satyryka jest kierować atak w jakąś stronę. Prawem jego jest także - przejaskrawić pewne fakty, i nie mam bynajmniej zamiaru z tych praw zrezygnować [...].

Autor zdefiniował swoje dzieło w terminach: powieści o oflagu, fantastyczności, karykatury, satyry i, pośrednio, typowości oraz prawdopodobieństwa („metoda syntetyczna”). Elementy, które już w nowym wstępie połączy kategoria groteski, mieszają się tu z postawą właściwą realizmowi, co po latach potwierdzi autokomentarz mówiący, że była to „proza tradycyjna w dziewiętnastowiecznej konwencji". Jej charakter najlepiej oddają zdania otwierające wersję z roku 1946: „Polski komendant trzeciego baonu był krótki, gruby i łysy. Wychudł nieco, więc mu się na karku pofałdowała skóra - ale brzuch pozostał okazały, jak za starych dobrych czasów". W wydaniu z roku 1964 nie znajdziemy rzecz jasna tego zdania, podobnie zresztą jak żadnego ze zdań w postaci, jaką odnajdujemy w zapisie pierwszej wersji powieści. Nowe otwarcie dzieła to ciąg przetworzeń inicjalnego obrazu „Prawe oczko czuwa, lewe oczko śpi”: „Lewe oczko czuwa, prawe oczko śpi. Kto śpi, kto czuwa?”, „Prawe (lewe) oczko czuwa, lewe (prawe) oczko śpi" ${ }^{29}$. Przy całej jednak stylistycznej odmienności obydwu wariantów tekstu wiąże je jednak ów oflagowy realizm, którego teorię wyłożył Wirpsza w pierwszym pomyśle na „przedsłowie”. Świat przedstawiony, zarówno w starej, jak i nowej postaci dzieła, zbudowany został z tych samych jednoznacznie identyfikowanych z obozem elementów, takich jak: baraki, prycze, druty, apele, strażnicy i naturalnie jeńcy, zwani tu z niemiecka „gefangenami”. Obydwie wersje wykorzystują te same motywy (planowania ucieczki, „zapamiętałego” spacerowania, nielegalnej rozbiórki wielkiej latryny, gotowania kartofli, przekupywania niemieckich strażników papierosami z paczek), opisują te same miejsca, choć w skrajnie często innej dyscyplinie języka.

Dla przykładu opis kawiarni obozowej w pierwotnym zapisie:

Kawiarnia obozowa stanowiła swego rodzaju curiosum. Był to lokal, którego wyglądu nie powstydziłaby się z pewnością żadna kawiarnia warszawska. Duże, wybite w ścianach ceglanego baraku okna, o które toczyła się półroczna przeszło walka z niemiecką komendą obozu, dawały wiele światła i stwarzały wrażenie przepychu - zwłaszcza, gdy się je porównało z ciemnymi, zadymionymi i, siłą rzeczy umiarkowanie brudnymi izbami, w których spędzała prawie cały swój czas większość mieszkańców obozu. Wlewająca się tędy fala światła uwypuklała piękne rzeźby z papier-mache, którymi pokryte były ściany i filary, podtrzymujące strop. [...] wnętrze kawiarni utrzymane było w stylu starożytnym, będącym umiejętną kompozycją elementów egipskich i rzymskich wybujałości [...].

${ }^{29}$ Wirpsza, Pomarańcze na drutach, 8-9. 
A oto opis tej samej kawiarni w wydaniu książkowym:

[...] barak z ceglaną podłogą, ongiś chyba magazyn, stoły, ławy, piecyk z menażkami wrzątku, neska podawana w kubkach, cena pięć papierosów amerykańskich ${ }^{30}$.

Porównajmy jeszcze opis sceny, w której uwięzieni oficerowie dyskutują strategie wojenne pochyleni nad mapą Francji. W wersji pierwszej:

Wszystkie stoły, jakimi rozporządzała sala, zostały zsunięte i na tym nowym, wielkim stole rozłożono mapę Francji, wykonaną ręcznie i na pierwszy rzut oka przypominającą mapę sztabową. Pochylało się nad nią w skupieniu kilka postaci, podczas, gdy pewien niski i przenikliwie chudy podpułkownik trzymał w ręku chorągiewkę na szpilce, pomalowaną w pasy i gwiazdy o barwach Stanów Zjednoczonych. Podobnymi chorągiewkami upstrzona była cała powierzchnia mapy - mieniły się na niej barwy francuskie, angielskie, amerykańskie i niemieckie.

I w wersji książkowej:

Major dyplomowany:

- Według zdania powołanego (szeroki, półokrągły rozmach dłoni nad stołem) do tego; tu jest, proszę panów mapa Francji; do tego zespołu; ona jest, oczywiście, w miarę; zasadnicze zręby planu; w miarę (rozmach pomniejszony) dokładna; zostały opracowane dostatecznie; ale powinna dla ogólnej (kółeczko nad stołem), to jest, z dostateczną precyzją; orientacji (palec w mapę) wystarczyć. Plan jest w gruncie rzeczy; sądzę, że kartograficznych; niezwykle (płaskie, pionowe cięcie powietrza otwartą dłonią) prosty; wątpliwości nie będzie ${ }^{31}$.

Z przywołanej sceny „narady sztabowej” prześledźmy jeszcze odpowiadające sobie wypowiedzi tej samej postaci. Najpierw zapis starszy:

- Czy rozumieją panowie ważność tego decydującego posunięcia? - zapytał z emfazą. - Czy zdajecie sobie sprawę z tego, że taki manewr jest nie tylko czynnikiem, który pozwoli rozstrzygnąć losy wojny na najistotniejszym jej teatrze, bo we Francji, na zachodzie - ale również, i to przede wszystkim, jest odrodzeniem polskiej myśli strategicznej, zasady ataku chorągwi pancernej w najsilniejsze zgrupowanie sił nieprzyjacielskich. Manewr ten, to powtórzenie Kircholmu i Wiednia, to triumf polskiej szkoły wojskowej!

W takiej natomiast postaci odnajdziemy to miejsce w powieści wydrukowanej:

- Proponowany przez nas; proszę panów, aby (półkole nad mapą); plan kampanii stanowi wariant; zechcieli spojrzeć na; bitwy pod Kircholmem; główną (płaskie cięcie dłonią) strzałkę. Polska doktryna wojskowa przewiduje ${ }^{32}$.

\footnotetext{
${ }^{30}$ Wirpsza, 17.

${ }^{31}$ Wirpsza, 40.

${ }^{32}$ Wirpsza.
} 
Eliptyczność i próba, parastenograficznego miejscami, odtworzenia żywej mowy, skutkujące ekspresją właściwą ówczesnej nowoczesnej poezji, decydują o trudności odbioru i nieuchronnych kłopotach z rozumieniem powieści w wersji ostatecznie oddanej do druku. Podobnie rzecz się ma z kluczową dla interpretacji całości potrzebą uchwycenia sensu nieoczywistego obrazu zawartego w tytule utworu, który bywa nawet uznawany za surrealistyczny ${ }^{33}$. W końcowej postaci dzieła narrator rozwija ten obraz w części „13”:

[...] a tymczasem cieplarnia to, oranżeria drutami otoczona, i owoce w niej dziwne dojrzewają, w pomarańczarni tej osobliwej, chronionej i strzeżonej (aby tylko nic złego się nie stało, wedle życzenia prześwietnych kontrahentów, którzy wzajem sobie możliwie wielkie krzywdy uczynić pragną), owoce dojrzewają, nastawać na to należy, najniewiarygodniejsze, a jednak rzeczywiste, realne i dotykalne, tak że zdawać by się mogło, że na drutach kolczastych, na kozłach hiszpańskich i zasiekach wyrastają złociste pomarańcze i po to zostały one te druty, kozły i zasieki pobudowane, aby rosły na nich pomarańcze i blask złocisty (co? roniły? rozsiewały? rozprzestrzeniały?) ${ }^{34}$.

Odrealniony, na wpół oniryczny, na wpół fantastyczny opis oflagowej przestrzeni prowadzić musi do rozumienia tytułu w kategoriach symbolu. Można domniemywać, że próbuje on oddać sprzeczności losu jenieckiego: niewola, której widomym znakiem jest drut kolczasty vs zapewnione w traktatach międzynarodowych bezpieczeństwo „oranżeryjnej egzystencji” osadzonych, prowadzące do iluzji wolności wewnątrz zamkniętej społeczności. W zarchiwizowanym przed-tekście tytułowy motyw występował w postaci bardziej rozbudowanej w rozdziale Jak wyrastaja pomarańcze. Jego obecność rozpoczyna się od wypowiedzi jednego z szeregowych:

Ale żeby takie pomarańcze kwitły, jak tutaj w głowach naszych panów, to nie może być. Przecież tam się ze szwabami biją, a do tego trzeba mieć głowę na karku. A tutaj? Daj któremu cekaem do ręki, to z przerażenia nie będzie wiedział co zrobić. $Z$ nimi to już koniec. Przed wojną niewiele byli warci, a te druty to już ich do reszty wykończyły...

Pogląd ten sprowokował dalszą wymianę zdań w baraku szeregowych z udziałem jednego z oficerów, który przypadkiem rzecz usłyszał:

- Ja tak myślę, że większość oficerów dlatego ma „bzika”, bo nie mają nic a nic do roboty. Człowiek, który pracuje, nie ma czasu na takie pomysły, jak kurs dla wojewodów, jaki sobie niektórzy panowie zorganizowali - i myślą przy tym, że naprawdę zostaną wojewodami, po powrocie do kraju!

Zagórski uśmiechnął się:

O tym kursie wojewodów słyszę od was już nie pierwszy raz. To rzeczywiście może razić człowieka, który się zajmuje czymś trudniejszym. Ale zauważcie: jest w obozie część ludzi, którzy z racji swej przedwojennej sytuacji byli na najlepszej drodze do zrobienia kariery. Wojna to przekreśliła. Co więcej, wiedzą oni, że po wojnie stosunki na świecie zmienią się radykalnie, a przede wszystkim

\footnotetext{
${ }^{33}$ Zbigniew Chojnowski, „'Zegar' i uwięzienie w powieści Witolda Wirpszy...”, 230

${ }^{34}$ Wirpsza, Pomarańcze na drutach, 91.
} 
zmienią się u nas, w Polsce. A do tego dochodzą druty - ta „choroba drutów kolczastych”. Każdy z nas - a oficerowie w znacznie większym stopniu, właśnie dlatego, że nie pracują - żyje w świecie nierzeczywistym, w świecie marzeń. I w tym świecie marzeń, jak w cieplarni, zakwitają te, jak wy je nazywacie, pomarańcze. Są to ostatnie sny o władzy.

To znaczyłoby, panie poruczniku - powiedział szewc Kowalski, że te pomarańcze kwitną właściwie na drutach a nie w głowach.

- Tak by z tego wszystkiego wynikało. - Porucznik Zagórski pochylił jeszcze bardziej głowę i uśmiechnął się do siebie.

W postaci końcowej dzieła wątek klasowy został wyeliminowany - tym samym też trudno do interpretacji tytułowego obrazu włączyć „sny o władzy”. Cała reszta sensów, tak jasno wyłożona na etapie przed-tekstu, pozostaje przydatna do wyjaśnienia tytułu powieści: pomarańcze symbolizują zatem nierzeczywisty świat marzeń zrodzony w cieplarnianych warunkach oflagowego bytowania. Są elementem fantastycznym skonfrontowanym z rzeczywistymi drutami okalającymi obóz, ale mimo wszystko o podejrzanej proweniencji, jaką da się zdefiniować potocznie w szeregu frazeologizmów nazywających wszelkie oderwanie od rzeczywistości.

Przegląd dokumentów genezy pozwala nam do tej próby zrozumienia powieści, i jej tytułu z wykorzystaniem przed-tekstu, dołożyć jeszcze jeden, być może kluczowy element. Pierwsza wersja utworu z roku 1946 skłania bowiem do postawienia pytania o „początek początku”, do próby odnalezienia „realnie istniejącej wskazówki pierwszego śladu”, jak nazwałby to Pierre-Marc de Biasi ${ }^{35}$. Wydaje się, że właściwy trop prowadzi do listów pisanych przez Wirpszę z oflagu w Gross Born do przyszłej żony Marii Kureckiej. W Książnicy Pomorskiej w Szczecinie zachowały się oryginały tych listów spisanych odręcznie na specjalnej papeterii dla jeńców. Uwagę czytelnika Pomarańczy na drutach powinien przykuć fragment z 20 sierpnia 1943 roku:

Mam zamiar odprawić dziwne nabożeństwo; posyłam na ul. Okolską kosz pomarańczy, winogron i czekolady (przecież Marylka ma 10 lat) i przez dziurkę od klucza patrzę, co się dzieje. Rezolutna dziewczynka przypuszcza atak, cynfolia chrzęści, tabliczka zostawia brunatny ślad na ustach. Wtedy otwieram drzwi, wchodzę cichutko na palcach, przekręcam kontakt i zasłaniam Marylce oczy. A ona mówi: „puść, bo ucieknę do Pani Szulc-Rembowskiej!” Jestem już grzeczny, zapalam światło i - zabieram się do pomarańczy, która jest duża, pełna i okrągła, jak wielki księżyc. A potem macham magiczną pałeczką, kosz bakalii zamienia się w piękny wazon z czerwonymi kwiatami a my - patrzymy się na siebie i śmiejemy się głośno, serdecznie i długo ${ }^{36}$.

List ten adresowany był na ul. Okolską w Warszawie, gdzie mieszkała podówczas jego adresatka. Nawiązuje jednak do przestrzeni i osób z okresu, kiedy respondenci, jeszcze jako dzieci, spotykali się w Gdyni i Gdańsku. Reminiscencja miesza się tu z marzeniem o nastawieniu prospektywnym, w którym zasadniczą rolę odgrywa potrzeba przemieszczenia się poza miejsce

${ }^{35}$ Pierre-Marc de Biasi, Genetyka tekstów, tłum. Filip Kwiatek i Maria Prussak (Warszawa: Wydawnictwo IBL, 2015), 202.

${ }^{36}$ Witold Wirpsza, Listy z oflagu, oprac., posłowiem i przypisami opatrzył Dariusz Pawelec (Szczecin: Zaułek Wydawniczy Pomyłka, 2015), 56-57. 
osadzenia, magiczny moment teleportacji i podróży w czasie zarazem. Pomarańcza wydaje się w tym marzeniu tylko jednym z wielu ekwiwalentnych składników. Jej obraz powróci jednak w kolejnym z listów (bez daty, stempel pocztowy z 25 kwietnia 1944 roku) jako dominujący, już na prawach niemal obsesyjnego motywu:

[...] aż wreszcie Ty, odsłaniając swe zęby, przegryzasz wraz z łupiną czerwoną, dużą pomarańczę - a górną wargę unosisz chyba po to, bym mógł zobaczyć Twoje różowe, delikatne dziąsła. Przypuszczam, że teraz już wiesz, o co mi chodzi. Czujemy, że zbliża się lato i słońce, jak olbrzymi, pomarańczowy zegar wskazywać będzie skwarne południe ${ }^{37}$.

Sensualność tej wizji zostaje wzmocniona w jej kolejnej odsłonie w tym samym liście:

A jeśli Cię to złości i masz ochotę gryźć lub drapać - uczyń to; nic mnie bardziej ucieszyć nie będzie w stanie. Chętnie zamieniłbym się w tym momencie w pomarańcz, aby uczuć dotyk różowego, świeżego i wilgotnego dziąsła ${ }^{38}$.

Pomarańcza jest w przywołanym zapisie marzenia synonimem tego, co tylko wyobrażone i niedostępne, ale jest też bez wątpienia nosicielem jednoznacznie pozytywnej wartości. Erotyka spleciona z egzotyką wyraża tu tęsknotę za wolnością, a pomarańcza symbolizuje przekraczanie ograniczeń rzeczywistej przestrzeni. Jej obraz obecny jest także w poezji Wirpszy, a co dla nas ważne, również w tej powstałej w obozie. W tekście otwierającym poemat Don Juan, którego pierwszą wersję tworzył poeta jesienią 1942 roku, pojawia się na przykład porównanie nieba do oksymoronicznej „śniadej pomarańczy”39. Pierwszy list do Marii Kureckiej nosi datę 17 listopada 1942 roku. Taki właśnie jest „mroczny obszar genezy”40 Pomarańczy na drutach. W listach i wierszach spisywanych w obozowym baraku, w przestrzeni otoczonej podwójnym częstokołem kolczastego drutu, objawił się po raz pierwszy ów „zagadkowy obraz” zawierający w sobie „zalążek dzieła” ${ }^{41}$. Z pewnością jego rozumienie ze świadomością tego, „z czego zrobiony jest początek”42, może być pełniejsze. Wirpsza, pisząc powieść, wyszedł od skondensowanego symbolicznego obrazu, z którego wyłonił się pierwszy pomysł, rozwijany w całkiem już tradycyjnej narracji, co możemy prześledzić w zachowanych fragmentach przed-tekstu. Stworzył utwór przejrzysty w swoich satyrycznych intencjach i w ramach konwencji zrozumiały. Po latach artystyczne wahadło powiodło go z powrotem do poetyckiego punktu wyjścia. Pierwszy zapis narracji uległ cięciom i przetworzeniom, poddanym dodatkowo „technice wariacyjnej”, zgodnie z którą poszczególne partie powracają jako swoje inaczej opracowane warianty. Miejsce jasności intencji zgodnej z czytelną konwencją zajęła „nadmierna komplikacja formalna” i „udziwnienia” językowe. Tradycyjna proza ustąpiła w gruncie rzeczy poezji, z której najpierw wzięła swój początek.

\footnotetext{
${ }^{37}$ Wirpsza, 84.

${ }^{38}$ Wirpsza, 85.

${ }^{39}$ Witold Wirpsza, Don Juan (Warszawa: PIW, 1960), 6.

${ }^{40}$ De Biasi, Genetyka tekstów, 202.

${ }^{41}$ De Biasi.

${ }^{42}$ De Biasi.
} 


\section{Bibliografia}

Balcerzan, Edward. „Człowiek Witolda Wirpszy”. Nurt, nr 2 (1965): 48-49.

Barańczak, Stanisław. „Na 60-lecie Witolda Wirpszy”. Kultura, nr 1 (1979): 102-107.

Błoński, Jan. „Dwaj poeci”. Twórczość, nr 3 (1950): 113-123.

Byliniak, Maciej. „Krytyka obrazu w poezji i eseistyce Witolda Wirpszy". Twórczość, nr 8 (2009): 54-82.

De Biasi, Pierre-Marc. Genetyka tekstów. Przetłumaczone przez Filip Kwiatek i Maria Prussak. Warszawa: Wydawnictwo IBL, 2015.

Chojnowski, Zbigniew. „'Zegar' i uwięzienie w powieści Witolda Wirpszy «Pomarańcze na drutach»”. W „W rytmie zegara...”. Wokót zagadnień chronozoficznych. Zredagowane przez Zbigniew Chojnowski, Beata Kurządkowska i Anna Rzymska, 228-242. Olsztyn: Wydawnictwo UWM, 2015.

„Istnieje porządek nieodgadniony”. O Witoldzie Wirpszy z Leszkiem Szarugą rozmawia Karol Samsel. Elewator, nr 23 (2018): 40-57.

Kuncewicz, Piotr. „Wirpsza i pozostali”. Przegląd Tygodniowy, nr 7 (1986), 13.

Libich, Maciej. „Epistolograficzny nośnik poezji. Osiem notatek o «Listach $\mathrm{z}$ oflagu» Witolda Wirpszy”. Elewator, nr 23 (2018): 14-29.

Marszałek, Rafał. „Eksperyment Wirpszy”. Nowe Ksiqż̇ki, nr 9 (1965): 402.

Nyczek, Tadeusz. „Śladem wzruszenia”. Poezja, nr 3 (1971): 22-30.
Pietrek, Daniel. „«Pomarańcze na drutach» - Witold Wirpsza w monachijskim wydawnictwie Carla Hansera". W Filologia trudnego sq̨siedztwa. Tom studiów dedykowany Profesorowi Markowi Zyburze w 60-lecie urodzin. Zredagowane przez Krzysztof Ruchniewicz we współpracy z Piotrem Przybyłą i Dariuszem Wojtaszynem, 228-241. Wrocław: Questio, 2017.

Słucki, Arnold. „Od «Sonaty» do «Drugiego oporu»”. Twórczość, nr 1 (1966): 116-119.

Strumiłowski, Artur. „Nowości prozy”. Życie Literackie, nr 44 (1965), 11.

Wirpsza, Witold, Kunstmann, Heinrich. „Salut Henri! Don Witoldo!”. Witold Wirpsza - Heinrich Kunstmann. Listy 1960-1983. Kraków: Universitas, 2015.

---. Don Juan. Warszawa: PIW, 1960.

---. Pomarańcze na drutach. Warszawa: PIW, 1964.

---. Listy z oflagu. Opracowane, posłowiem i przypisami opatrzone przez Dariusz Pawelec. Szczecin: Zaułek Wydawniczy Pomyłka, 2015. 


\title{
SŁOWA KLUCZOWE:
}

powiest $\quad$ przed-tekst

\section{Witold Wirpsza}

\author{
Listy z oflagu
}

\begin{abstract}
AbSTRAKT:
Szkic przedstawia nową interpretację powieści Witolda Wirpszy Pomarańcze na drutach (1964), możliwą dzięki mikroanalizie przed-tekstów. Są to przede wszystkim materiały z archiwum pisarza zachowane w Książnicy Pomorskiej w Szczecinie, w tym 39 kart maszynopisu zawierających polski tekst pierwszej redakcji powieści z jesieni 1946 roku oraz listy pisane przez Wirpszę z oflagu w Gross Born do przyszłej żony Marii Kureckiej. Wczesny odbiór Pomarańczy na drutach zdominowany został przez pytanie o jej formę oraz uznanie formy poetyckiej jako wyznacznika wartości i gwarancji sensu tego prozatorskiego przedsięwzięcia. Autor interpretacji wychodzi od pytania, czy na tle istniejących dokumentów recepcji uprawnione będą interpretacyjne sugestie dokonywane ponad językową i „poetycką” tkanką tekstu, czy zasadne będzie wskazanie klucza do rozumienia powieści poza jej nastawieniem na sam język i poza właściwościami typowymi dla nurtu lingwistycznego w poezji, z którym kojarzony jest Wirpsza. Interpretacja odwołująca się do śladów pozostawionych w przed-tekstach wychodzi od rozumienia tytułu w kategoriach symbolu, powiązanego z odrealnionym, onirycznym, na wpół fantastycznym opisem oflagowego świata przedstawionego. Przegląd dokumentów genezy pozwala włączyć do próby zrozumienia powieści i jej tytułu, oprócz pierwszej wersji utworu z roku 1946, listy autora powstałe w bezpośredniej relacji z powieściową czasoprzestrzenią. Według niniejszej propozycji interpretacyjnej przynoszą one odpowiedź na pytanie o „początek początku”, albowiem to w nich właśnie odnaleźć można „realnie istniejące wskazówki pierwszego śladu" (wedle terminologii, jaką proponuje Pierre-Marc de Biasi).
\end{abstract}


praktyki | Dariusz Pawelec, Pomarańcze na drutach Witolda Wirpszy...

\section{groteska}

\section{NOTA O AUTORZE:}

Dariusz Pawelec (ur. 1965) - profesor w Instytucie Literaturoznawstwa Uniwersytetu Śląskiego w Katowicach. Opublikował m.in. książki: Poezja Stanisława Barańczaka. Reguły i konteksty (1992), Lingwiści i inni. Przewodnik po interpretacjach wierszy współczesnych (1994), Czytając Barańczaka (1995), Debiuty i powroty. Czytanie w czas przetomu (1998), Świat jako Ty. Poezja polska wobec adresata $w$ drugiej połowie XX wieku (2003), Od kołysanki do trenów. Z hermeneutyki form poetyckich (2006), Wirpsza wielokrotnie (2013). Zredagował antologie: Powiedz prawdę. Antologia poezji pokolenia '68 (1990), Martwe punkty. Antologia poezji „Na Dziko” (1994-2003) (2004, także wydanie słowackie i czeskie), Tropy „Na Dziko”. Postantologia (2019). Opracował edycję utworów Witolda Wirpszy: Sonata i inne wiersze do roku 1956 (2014), Listy z oflagu (2015), Varia. Eseje. Prozy (2016), Sama niewinność. Powieść (2017), Apoteoza tańca (2018), Umieralnia i inne utwory dramatyczne (2019). 